\title{
As diferentes faces da razão (II). Risco, ciência e peritos
}

The different face of reason (II). Risk, science, and experts

Les différentes faces de la raison (II). Risque, science et experts

C. M. Novais Madureira e Carlos Marinho Rocha

\section{CpenEdition}

\section{Journals}

Edição electrónica

URL: http://journals.openedition.org/rccs/1235

DOI: $10.4000 /$ rccs. 1235

ISSN: 2182-7435

\section{Editora}

Centro de Estudos Sociais da Universidade de Coimbra

Edição impressa

Data de publição: 1 Dezembro 2002

Paginação: 81-106

ISSN: 0254-1106

\section{Refêrencia eletrónica}

C. M. Novais Madureira e Carlos Marinho Rocha, «As diferentes faces da razão (II). Risco, ciência e peritos », Revista Crítica de Ciências Sociais [Online], 64 | 2002, colocado online no dia 01 outubro 2012. criado a 01 maio 2019. URL : http://journals.openedition.org/rccs/1235; DOI : 10.4000/rccs.1235

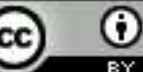




\section{M. NOVAIS MADUREIRA \\ CARLOS MARINHO ROCHA}

\section{As diferentes faces da razão (II). Risco, ciência e peritos}

Em texto anterior argumentou-se contra os excessos do cientismo com que, na linha de Sokal e Bricmont, António Manuel Baptista ataca as análises sociológicas dos processos e produtos da ciência, nomeadamente as posições de Boaventura de Sousa Santos. Neste outro texto, pretende-se contestar AMB e os sokalistas no seu próprio campo, o da ciência pura e dura, mostrando que eles próprios não compreendem o estatuto das suas ciências, e tentando ponderar afirmações menos precisas, frequentes na análise da sociogénese da ciência. Trazendo a discussão para o nosso tempo, abordaremos também uma problemática não tratada no texto anterior, a do estatuto dos cientistas e tecnólogos enquanto peritos nas instâncias de decisão. Por último, tratará de analisar-se como as controvérsias entre peritos, hoje tão frequentes, são vividas no seio da comunidade científica e qual a evolução que geram na própria prática pericial.

Cultura e civilização são outros tantos termos vagos que podemos divertir-nos a diferenciar, a opor e a conjugar. Para mim, trata-se de um capital em vias de formação, constituído por coisas, objectos materiais - livros, quadros, instrumentos - que têm apenas uma duração provável, uma fragilidade evidente, a precariedade das coisas. Mas este material não basta: tal como um lingote de ouro, um hectare de terra ou uma máquina não são capital na ausência de homens que deles precisem e que deles se saibam servir, isto é, no nosso caso, de homens com sede de conhecimento e de poder de transformação interior, com sede de desenvolvimento das suas sensibilidades, e que saibam, por outro lado, adquirir ou exercer um mínimo de hábitos de disciplina intelectual e de práticas para utilizar os documentos e instrumentos que os séculos nos legaram. Ora, o que produz a crise desse capital cultural é precisamente a escassez de homens que saibam ler - virtude perdida -, de homens que saibam ouvir e mesmo escutar, que saibam re-ler, re-ouvir e re-ver. 


\section{Proposição}

Em texto anterior (Rocha e Madureira, 2002), dominado pelo estilo próprio e a formação pessoal do aqui segundo autor (e então primeiro), argumentou-se em termos filosóficos, históricos, culturais e de senso comum contra os excessos do cientismo com que, na linha de Sokal e Bricmont, António Manuel Baptista (AMB) ataca as análises sociológicas dos processos e produtos da ciência, nomeadamente as posições, de resto já não recentes, de Boaventura Sousa Santos (BSS). E procurou fazer-se isso sem ignorar algumas fragilidades da argumentação "sociologista" que AMB apelida, revelando nisso alguma confusão conceptual ou mesmo ignorância, de "pós-moderna".

Neste outro texto, em que, por contraposição, deliberadamente se deixam predominar a formação e o estilo pessoais do primeiro autor, pretende contestar-se $\mathrm{AMB}$ e os sokalistas no seu próprio campo, o da ciência pura e dura, mostrando como eles próprios não compreendem o estatuto das suas ciências, e tentando, no decorrer desse processo, ponderar afirmações menos precisas, em alguns casos ingénuas, frequentes na análise da sociogénese da ciência. Procurando trazer a discussão para o nosso tempo tão tipicamente sincrético e a-filosófico, abordaremos também uma problemática não tratada no texto anterior, mas que cremos ${ }^{1}$ estar presente no subconsciente de alguns dos polemizantes, a do estatuto dos cientistas e tecnólogos enquanto peritos nas instâncias de decisão e nas discussões públicas dos riscos tecnológicos.

Antes de mais, porém, notaremos que $\mathrm{AMB}$ e os sokalistas, entrincheirados no fascinante, mas atípico, compartimento físico-teórico da ciência, querem colocar-se fora do seu tempo, em uma época em que uma parte da humanidade sacralizava a ciência e em que a tecnologia, então apenas emergente de práticas "simplesmente" técnicas, mas progressivamente cientifizadas, era quase universalmente considerada como amigável e benfeitora. Com efeito, estes e outros filhos do positivismo comtiano ignoram ou esquecem um certo número de factos tipicamente contemporâneos, a saber:

(i) que o conhecimento científico é hoje, na sequência da socialização e estatização ocorridas no contexto do esforço colectivo da II Guerra Mundial, indissociável da acção técnica, ${ }^{2}$ tanto na sua génese como na exploração

\footnotetext{
${ }^{1}$ Com efeito, não acreditamos que a violência da reacção retardada de AMB a uma obra antiga de BSS possa ser completamente desligada das recentes posições públicas deste na questão da co-incineração de resíduos industriais perigosos, cujos argumentos, aliás, não podemos subscrever na totalidade (cf., adiante, o caso do município de Cambridge $v s$. Universidade de Harvard).

${ }^{2} \mathrm{Na}$ realidade, a distinção entre ciência e tecnologia, enquanto práticas profissionais, foi desaparecendo paulatinamente e quase não tem sentido desde há meio século a esta parte. Porque, porém, continua a ter todo o sentido e oportunidade distinguir o pensamento científico do pensamento
} 
das suas respectivas potencialidades e, nem que fosse só por isso, não é nem neutro nem inócuo e que, apesar de algumas confusões residuais, a Humanidade e o humanismo acordaram há já mais de meio século para esse facto;

(ii) que existe toda uma enorme diferença de escopo e de implicações entre uma ciência clássica praticada por uma aristocracia de homens de lazer, diletantes curiosos da relojoaria do mundo superficialmente bem-ordenado em que viviam, e uma ciência contemporânea, institucionalizada, profissionalizada e sindicalizada, em que a produção científica tem - para o bem e para o mal - um valor económico como o de qualquer produção material ou energética, valor que é reconhecido e aceite tanto pelos seus praticantes como pelos seus exploradores, e como tal colocada no mercado, com todas as consequências; e, mais, que a institucionalização da Ciência segundo a táctica industrialista da divisão do trabalho permite hoje o acesso ao processo de produção científica de massas de indivíduos culturalmente limitados (mas, por isso mesmo, tecnicamente eficazes enquanto operários de fábrica ou peças de máquina - os Fachidioten da análise marxiana) que, mais tarde ou mais cedo, acedem aos escalões de planeamento e decisão, o que não pode deixar de ter reflexos sobre a natureza e qualidade do próprio pensamento científico;

(iii) que, em consequência da sua aliança com a tecnologia e condicionada, tanto pela potência dos instrumentos de observação, de medida e de cálculo que esta lhe fornece, como pela visão holística que lhe propõe, ${ }^{3}$ a ciência se afastou hoje irreversivelmente do paradigma clássico de "arte do solúvel” caracterizado pela analiticidade, pelo reducionismo e pelo simplismo do preconceito matemático da linearidade e que, por esse facto, perdeu por completo a tranquilidade das visões exteriores e descomprometidas com tudo excepto consigo mesma; por força do choque com uma realidade que obstinadamente se recusa a ser decomposta, reduzida e simplificada, o olhar clássico da ciência sobre o mundo encontra-se hoje dilacerado por uma rede de contradições e incompletudes internas - que, para-

tecnológico, manteremos, em benefício de alguma clareza do discurso, a distinção terminológica na falta de um termo unificador consagrado (como poderia ser, por exemplo, "tecnociência"). Também em benefício da clareza, notaremos que estamos habituados a marcar uma distinção muito nítida entre técnicas, enquanto perspectivas imediatistas sobre os meios de transformação da natureza, a que mais precisamente chamamos modos técnicos de produção, e tecnologia, enquanto perspectiva racionalizada e integrada sobre esses modos de produção e sobre as próprias técnicas e os seus modos de intervenção no mundo.

${ }^{3}$ Com efeito, a tradição metodológica da ciência é fundamentalmente analítica enquanto a da tecnologia, como claramente se vê na sua formalização como teoria dos sistemas, é intencionalmente holística e não poderia deixar de sê-lo. 
doxalmente, matemáticos como Veblen, Gödel, Loewenheim e Skolem foram os primeiros a identificar e se revelou sobretudo com a crise ocasionada pela interpretação de Copenhaga da dualidade quântica - e mergulhado numa depressão hipersensível a toda a crítica de que nem o optimismo neo-pragmatista de Tarski e dos "informáticos" parece ter podido tirá-lo;

(iv) que atribuir às técnicas cientifizadas o estatuto de infalibilidade e de invariável justeza e beneficência que hoje nem a ciência tem é tão estulto como pretender que todas as afirmações de um cientista são infalivelmente correctas e justas pelo simples facto de provirem de uma boca abençoada pela ciência.

Mostraremos e ilustraremos o modo como pôde ter-se gerado uma tal revolução, no estrito sentido original de reviravolta, e, sem que aqui, por não ser esse o objectivo primário, se procure justificar a proposta de que $a$ assunção plena de uma versão moderada da referencialidade cultural identificada pela análise sociológica pode defender a ciência e a tecnologia actuais da exploração por grupos de interesses económicos e restituir-lhe as suas raizes bumanas e a alegria da aventura bumana do conbecimento, tal assunção estará inevitavelmente subjacente à presente exposição.

\section{Risco tecnocientífico}

Um dos modos de caracterizar a civilização em que vivemos desde meados do século XX é como "sociedade do risco", em referência ao advento surpreendentemente brusco de uma consciência universal (na ressaca do trauma colectivo produzido pela perigo nuclear da guerra fria) da multiplicidade das ameaças que pesam sobre a humanidade, se esta continuar a permitir que os mecanismos económicos persistam, na perspectiva míope do lucro imediato, em estimular o uso irreflectido das novas tecnologias de rosto científico. $\mathrm{Na}$ realidade, trata-se apenas de uma reacção tipicamente leiga à "descoberta" de um facto que nada tem de novo, o princípio de entropia, ou segundo princípio da Termodinâmica, segundo o qual toda a intervenção humana intensa e em larga escala sobre um mundo finito como é o nosso implica necessariamente, no curto prazo, modificações significativas, eventualmente irreversíveis e, em todo o caso, altamente imprevisíveis, do estado físico e termodinâmico das vizinhanças imediatas e, no longo prazo, da totalidade do planeta. Que não seja de todo certo que tais modificações sejam todas necessariamente ameaçadoras para a sobrevivência da humanidade ou de algumas comunidades humanas, é perfeitamente irrelevante: a "ameaça" é óbvia para a nossa maneira actual de viver o que, de resto, é natural porque uma tal intervenção se destinou, desde o início, a, de algum modo, modificar a maneira de viver de alguém (pelo menos daqueles que 
com ela lucram directamente). O que é inegável é que simples nomes como Seveso, Minamata, Bhopal, Three Mile Island, Tchernobyl, Amoco Cadiz e Exxon Valdez, por exemplo, são suficientes para fazer tremer qualquer um de nós.

Ora, se essas intervenções são necessariamente de natureza técnica ou tecnológica, o facto é que o engenheiro é uma figura relativamente pacífica, senão burlesca, da nossa sociedade e o médico, mesmo quando tecnocrata ou explorador, é de todo imprescindível, enquanto o cientista - que o imaginário popular distingue do engenheiro e contrapõe ao engenheiro - tem um perfil potencialmente sinistro, não só em consequência de imagens arquetípicas como as do Dr. Frankenstein e do Dr. Jekyll mas porque o que as pessoas realmente mais temem é aquilo que desconhecem; e é um facto que o comum dos mortais desconhece e reconhece desconhecer a ciência, enquanto desconhece mas supõe conhecer a tecnologia, só porque pensa conhecer os seus produtos. Assim, injusta mas inelutavelmente, a ciência, e não os desvarios cientistas enquanto suas ideologizações, é o grande papão do nosso tempo.

Ora, na origem de tal situação estão, em grande parte, os próprios cientistas: em primeiro lugar, porque, deliciados com o estatuto que supostamente lhes dão as suas torres de marfim, há séculos que não cuidam de mostrar publicamente o que são, realmente, a sua actividade e os seus produtos (e também as respectivas lacunas e limitações, deixando, por omissão, por insinuação ou directamente por afirmação, o leigo crer que estas não existem), isto é, não cuidam de minimamente se fazer compreender pelo público $;{ }^{4} \mathrm{em}$ segundo lugar porque, ciosos como são de distinguir internamente a ciência "pura" da "outra", não hesitam em, para consumo externo, mimetizar-se em tecnólogos ${ }^{5}$ (mesmo sendo certo que a isso são pressionados pelos critérios economicistas de financiamento da investigação), assim contribuindo para a confusão das responsabilidades; finalmente, porque não hesitam em fazer as mais espúrias alianças com essa, mais que todas, pseudociência, a Economia, cujos fundamentos científicos são mais do que

\footnotetext{
${ }^{4}$ E a melhor prova desta afirmação é o estado lamentável em que se encontra o ensino público das ciências, marcado pela ineficácia, pelo insucesso escolar e pela promoção de um verdadeiro horror às disciplinas científicas (maxime à matemática); por um efeito de acção em retorno, muitos cientistas praticantes, mesmo que o quisessem, seriam hoje incapazes de divulgar a ciência que supostamente praticam. No entanto, observa-se com curiosidade que, quando um ramo adopta uma política de divulgação eficaz, mesmo quando ocasionalmente superficial e pouco correcta, como são hoje os casos, por exemplo, da Astronomia e da Biologia Molecular, mesmo esse horror genérico é facilmente vencido pelos jovens à procura de um curso superior.

${ }_{5}$ É igualmente certo que, perversamente, aos tecnólogos não desagrada de todo serem tratados nos media como cientistas.
} 
duvidosos e cuja única função social é a de justificar, pseudoteorizando, o status quo dos mecanismos de distribuição da riqueza, ${ }^{6}$ mediante o artifício clássico do non sequitur: atacar um problema desenvolvendo um raciocínio sobre hipóteses tácitas que lhe são inaplicáveis e demonstrar a justeza de uma das suas conclusões pelo rigor do raciocínio.

Em face destes argumentos, que qualquer leigo culto pode facilmente alinhar, parece inteiramente legítimo que a opinião pública exija um estudo externo sério dos mecanismos internos da ciência e que os sociólogos satisfaçam essa exigência. Na realidade, é experiência pessoal de, pelo menos, um de nós, que tal estudo tem ajudado a compreender melhor o papel e o desenvolvimento da ciência no mundo actual. A única coisa que, nesta matéria, pode censurar-se a alguns sociólogos é aspirarem hoje a uma cientificidade à maneira obsoleta da Física teórica.

\section{Ciência física, tecnologia e ciência, simplesmente}

À tarde Baudolino começou a narrar mais expedito, e Niceta decidiu não tornar a interrompê-lo. Queria vê-lo crescer depressa, para chegar ao que interessava. Não havia compreendido que ao que interessava ainda não chegara Baudolino, naquele momento em que estava a contar, e contava precisamente para lá chegar.

UMBERTo ECO, Baudolino

Por uma lógica estranha, a ciência perturba-nos como a fé perturbou os nossos pais...

Emile Zola, Le Figaro, 18 de Dezembro de 1866

Diz-se cientificamente culto aquele que, perante a notícia de um novo avanço científico, é capaz de avaliar o seu significado e alcance reais e de descontar os exageros com que, demasiado frequentemente, os jornais e revistas de divulgação (e, por vezes, até as publicações científicas propriamente ditas) divulgam as novas descobertas.

Mas, para ser cientificamente culto, é necessário possuir, em todas as várias disciplinas, o mesmo elevado grau de conhecimento, isto é, ser especialista de todas as especialidades de um domínio institucionalizado e corporativizado? A experiência do próprio trabalho científico especializado mostra (pondo de lado eventuais dificuldades terminológicas) que não é este o caso: do mesmo modo que se pode ser literariamente culto conhe-

\footnotetext{
${ }^{6}$ Com efeito, nunca vimos, por exemplo, um matemático denunciar o uso ilegítimo de uma das suas teorias para formalizar um modelo macro- ou micro-económico de pressupostos idiotas; pelo contrário, é fácil citar matemáticos (v.g., von Neumann, Nash) que não hesitaram em aplicar os seus conhecimentos sobre hipóteses as mais irrealistas, quando não absurdas.
} 
cendo de modo relativamente profundo apenas um número limitado de clássicos, pode esperar construir-se uma certa cultura científica apenas sobre certos conhecimentos essenciais, desde que se cumpram duas condições suplementares, ambas necessárias, mas nenhuma estritamente suficiente: (i) a de que se tenha desenvolvido uma aparelhagem crítica adequada à identificação das dificuldades e limitações do trabalho científico e (ii) a de que se tenha, de algum modo, construído essa misteriosa capacidade de gozosa fruição intelectual do conhecimento científico, mesmo em áreas afastadas da nossa.

Ora, por força de uma lamentável tradição já secular, a primeira destas condições suplementares é bem mais difícil de obter de um homem de ciência do que de um homem das humanidades. ${ }^{7}$

Aparentemente, trata-se de consequência da (conhecida, reconhecida, mas raramente analisada) carência, na prática da ciência institucionalizada, de uma profissão de crítico, independente e publicamente assumida. Com efeito, esse papel deveria ser desempenhado pela estranha figura institucional dos referees, juízes em causa própria, que, por não menos estranha convenção institucionalizada, escondem a cara, o nome e a mão ${ }^{8}$ e, na prática, funcionam mais como censores que como críticos. Seja como for, uma consequência extremamente grave de tal carência é o facto frequente de passar sem qualquer crítica uma aplicação ilegítima e errada de um instrumento ou conceito de uma área por um especialista de outra área a um problema da sua especialidade (o caso mais corrente e gritante é o da aplicação da estatística a áreas como a Medicina ou a Sociologia, mas o reverso, a aplicação inconsciente ou não suficientemente conceptualizada, nas próprias ciências, de derivações da "linguagem comum" ou de conceitos, analogias e metáforas oriundas da filosofia, das humanidades ou da economia, é menos raro do que se quer fazer crer).

Ora, para poder cumprir a primeira daquelas condições, o homem de ciência teria, antes de mais, que tomar consciência das lacunas da descrição que a ciência clássica dá do mundo, mas, se essas lacunas são conhecidas de

\footnotetext{
7 Notar-se-á, porém, não sem alguma surpresa, que é mais comum ter um homem de ciência alguma capacidade de fruição e apreciação de uma obra artística em termos comuns do que um homem de letras, por exemplo, fruir e apreciar uma obra científica como criação cultural; trata-se, como veremos, dos estranhos efeitos de, por um lado, uma incapacidade de comunicação por parte de uma ciência que se toma a si própria como produto (definitivo) e não como processo, o que resulta numa profunda inabilidade para a compreensão dos seus próprios passos e, em última análise, na inevitável falta de qualidade do ensino científico. Por outro lado, trata-se também de um recalcado (mas bem evidente na frequente aspiração a um estatuto de cientificidade) complexo de inferioridade das humanidades induzido pela atitude inacessível, e por vezes raiando a sobranceria, da ciência, atitude que frequentemente convence o cidadão comum e os media.

8 Tratar-se-á de uma outra versão da "mão invisível" da economia de mercado?
} 
alguns especialistas - infelizmente demasiado raros -, elas são sempre cuidadosamente passadas em silêncio em nome da preservação do respeito pelo prestígio universal da ciência, do qual os cientistas vivem. Por isso, a verdadeira cultura científica é tão rara, até entre cientistas, não só porque estes raramente compreendem o processo científico em toda a sua profundidade, mas também porque os que efectivamente o compreendem raramente contribuem, expondo não só os sucessos, mas também as limitações, as frustrações e as dilacerantes contradições internas com que diariamente se defrontam, o que fecha um círculo vicioso.

A marcha da ciência clássica apoia-se essencialmente sobre dois pilares: a noção de "lei científica objectivamente existente", ficção útil mas indemonstrável, e a prática do controlo experimental que, como bem sabemos, apenas pode refutar uma teoria errada, mas nunca confirmar uma outra, mesmo que fosse correcta. ${ }^{9}$ Deste ponto de vista, ao exibir leis quantitativas rigorosas que permitem a previsão e o controlo pela experiência, a Física propõe aos outros ramos do conhecimento um ideal de cientificidade inultrapassável, provavelmente impraticável e, em todo o caso, de que se poderia questionar sempre o interesse real.

Porém, o que a maior parte das pessoas, incluindo muitos físicos ${ }^{10}$, ignora é que esta cientificidade não vale senão para a Física dita fundamental ou teórica, para a qual a estrutura do espaço e do tempo e dos seres físicos (matéria e radiação) neles mergulhados se descreve em termos dos vários grupos de simetria (v.g., simetria de translação, ou homogeneidade, simetria de rotação, ou isotropia) das quais, como, desde Emmy Noether e Erwin Schrödinger muito bem se sabe, resultam os princípios de conservação ou de invariancia (da energia, para a homogeneidade do tempo, da quantidade de movimento, para a homogeneidade do espaço, do momento cinético, para a isotropia do espaço ${ }^{11}$ ), que são válidas tanto para o infinitamente pequeno como para o infinitamente grande. Por consequência, o domínio regido por estas leis estritas da Física teórica é conceptual e praticamente muito limitado: escapa-lhe toda a parte do real que mais nos interessa, a saber, a matéria "banal" do nosso ambiente macroscópico imediato e, por

\footnotetext{
9 É sugestiva, e merece a mais detida atenção, a semelhança entre este enunciado que, desde Popper, nos habituámos a considerar trivial e o da muito menos óbvia indemonstrabilidade da coerência interna de um sistema formal, enunciada por Goedel.

${ }^{10} \mathrm{Na}$ melhor exposição elementar que conhecemos sobre os princípios fundamentais da Física moderna, o autor, um físico do estado sólido que por vergonha não identificaremos, afirma na sexta linha da introdução: "Na segunda metade do século XX, a Física transformou-se em conhecimento total, universal, dos fenómenos naturais."

${ }^{11}$ Dado, porém, que o tempo não é isótropo (ou reversível), a entropia não é, como se sabe, conservativa, pelo que o Universo não é estático, mas evolutivo.
} 
maioria de razão, aquela de que somos feitos, a matéria viva. Não se trata, obviamente, de a matéria comum escapar às leis fundamentais da Física, mas apenas do facto incontrovertível de essas leis - tais como as conhecemos e aplicamos - serem totalmente incapazes de fornecer uma descrição com capacidade de previsão do comportamento local da matéria, orgânica ou inorgânica. Esta incapacidade tem uma razão muito mais profunda e evidente do que a tão frequente como falsamente invocada "complexidade" dos fenómenos naturais: ${ }^{12}$ essas leis físicas estão indissoluvelmente ligadas às simetrias do espaço-tempo (que, aliás, explicam a sua "tratabilidade" matemática ${ }^{13}$ ), mas a matéria - por força da descontinuidade que introduz no universo perceptível - quebra de modo permanente essas simetrias e essa quebra de simetria não pode ser descrita por meio de leis simétricas. ${ }^{14}$ Deste modo, as leis fundamentais não podem aplicar-se-lhe senão sob a forma de leis integrais ou estatísticas que são estruturalmente incapazes de prever os pormenores da evolução macroscópica de tal ou tal descontinuidade localizada como fenómeno perceptível. ${ }^{15}$

Tem o leitor dificuldade em compreender afirmações tão gerais e abstractas ou necessita de exemplos concretos para delas se deixar convencer? ${ }^{16}$ Tome-se então o seguinte facto, um apenas entre inúmeros outros igualmente fáceis de invocar: a noção teórica de "equilíbrio termodinâmico" ou, para o leigo, simplesmente "equilíbrio de um sistema físico" implica, em termos teóricos estritos, a homogeneidade perfeita do meio a que se aplica e, em particular, a ausência de fronteiras, isto é, o seu carácter ilimitado, ou

${ }^{12}$ No século passado, a "mecânica racional" recusava liminarmente tratar a existência que não negava ser inegável dos fenómenos triviais do atrito e da dissipação da energia, com base naquilo a que, referindo-se no fundo à sua complexidade, chamava a sua "irracionalidade" (isto é, a sua irredutibilidade à simplicidade dos princípios teóricos) e remetia-a a para a "mecânica técnica"; hoje não nos passa pela cabeça defender tal opção, mas continuamos a utilizar o conceito de "irracionalidade" sob o nome actualizado de "complexidade" que apenas deve significar que a realidade não é tão simples quanto a Física clássica a supunha. Em casos extremos, que relevam já da patologia conceptual, chega mesmo a falar-se de "caos" quando deveria dizer-se apenas "não-linearidade”, tal é o grau de incompreensão dos físicos quanto aos fundamentos da sua própria ciência. ${ }_{13}$ Note-se, de passagem, que esta afirmação decorre, generalizando, do programa de Erlangen do célebre geómetra Felix Klein: a tratabilidade matemática de um problema decorre da possibilidade de o formular em termos de operações que possuam uma estrutura de grupo.

${ }^{14}$ E daí a persistente recusa do atomismo pelos físicos, mesmo quando os químicos e os cristalógrafos já tinham demonstrado a inevitabilidade da sua aceitação. Como S. Tomé, os físicos só o aceitaram quando Max von Laue lhes mostrou uma fotografia e por isso lhe deram o Nobel no ano seguinte ao da sua publicação. Esta coexistência contraditória, em Física, do "discreto" ou "atomístico" com o "contínuo" constitui, provavelmente, o seu mais profundo e delicado problema conceptual e metodológico.

${ }^{15}$ A absoluta incapacidade de os físicos clássicos aceitarem este facto elementar levou ao suicídio o primeiro que o detectou, embora sem o compreender completamente, o físico austríaco Ludwig Boltzmann e também, mais tarde, o seu discípulo, Paul Ehrenfest.

16 Trata-se, então, provavelmente, de um físico. 
seja, a sua infinitude, atributo que, obviamente, se não aplica a nenhum sistema real. Assim, apesar dos magníficos e sofisticadíssimos modelos teóricos da mecânica quanto-estatística, a teoria geral dos estados físicos da matéria encontra-se ainda em estado extremamente rudimentar e as próprias mudanças de estado, embora extremamente familiares, são-nos ainda hoje largamente incompreensíveis. ${ }^{17}$ Os comportamentos colectivos das mais pequenas porções de matéria, que, na lógica analítica da ciência clássica, deveriam ser, mediante uma combinatória adequada, consequência directa das propriedades individuais dos átomos, recusam-se obstinadamente a deixar-se deduzir delas. Se, por exemplo, tomarmos uma molécula - mesmo tão simples como a da água - a teoria é, ainda hoje, incapaz de prever o seu diagrama de fases, isto é, coisas tão simples como a temperatura a que ferve ou congela, em que simetria cristaliza a cada pressão e temperatura, etc. Curiosamente, porém, a simulação computacional do comportamento de agregados atómicos e moleculares, com base nas leis fundamentais da Física, começa hoje a permitir prever fenomenologias deste tipo, o que faz pensar em uma eventual incompletude ou mesmo em uma drástica inadequação dos instrumentos matemáticos hoje ao nosso dispor. ${ }^{18}$ Porém, para, no quadro da Física clássica, descrever - sem os compreender - comportamentos como estes, temos que recorrer ao que chamamos a "termodinâmica dos processos irreversíveis" ou "cinética física", um outro tipo completamente diferente de "teoria" ainda em construção, na qual, com base apenas em argumentos de plausibilidade extraídos da teoria clássica das equações diferenciais, ${ }^{19}$ postulamos certas formas matemáticas para a descrição quantitativa dos fenómenos, mas temos que recorrer sistematicamente à experiência para determinar os valores dos seus parâmetros em cada caso particular - isto é, temos um vago quadro formal que deve, em cada caso, ser preenchido com dados empíricos, mas não temos absolutamente nenhuma teoria, seja qual for o sentido rigorosamente clássico que queiramos dar à palavra.

\footnotetext{
17 Assim, por exemplo, não dispomos ainda hoje de uma demonstração cabal da estabilidade do estado cristalino. Do mesmo modo, um de nós ensinou durante muitos anos que o estado cristalino (isto é, sólido ordenado) é incompatível com a simetria quinária até que, em 1984, o físico americano Steinhardt, apoiando-se sobre os trabalhos geométricos do matemático britânico Roger Penrose, descobriu uma simetria quinária compatível com a ordem a longa distância, que não tardou a ser encontrada em figuras de difracção de ligas Al-Mn. Que a estas novas configurações do estado sólido se não chame cristais, mas "quase-cristais", é irrelevante e resulta apenas de prudência face ao recente reconhecimento do vacilante estatuto do estado cristalino.

${ }_{18}$ Pense-se, por exemplo, no ataque de Schrödinger à adequação do instrumento matemático "derivada" para definir o conceito físico de velocidade e nas suas consequências sobre o próprio conceito de determinismo.

${ }^{19} \mathrm{Na}$ base das quais está, aliás, um postulado tácito de continuidade (porque em um ponto de descontinuidade não existe derivada).
} 
Chegados aqui, é bom que meditemos um pouco nas sábias palavras de P.A.M. Dirac:

O objectivo fundamental da Física não é a construção de descrições, mas a descoberta das leis que governam os fenómenos, assim como a aplicação dessas leis à descoberta de novos fenómenos. Se existir uma descrição, tanto melhor, porém, a questão de existir ou não uma descrição tem apenas interesse secundário. (Dirac, 1995)

Se este ponto de vista é classicamente correcto - e é difícil negar que o seja - então, teremos que confessar que aquilo a que correntemente se chama "Ciência dos Materiais" ou "Física do Estado Sólido" não é, na realidade, senão engenharia dos materiais ou engenharia do estado sólido, ${ }^{20}$ eventualmente praticada por físicos que tentam persistente e corajosamente aplicar o "método científico" (que, como se sabe desde Einstein e Feyerabend, não é um método, mas a aplicação persistente da inteligência, da imaginação e do pensamento divergente abdutivo) a um conjunto de problemas que se encontram ainda em estado pré-teórico. $\mathrm{O}$ inegável mérito de tal esforço não concede, porém, automaticamente, aos seus resultados o desejado estatuto da inatingível cientificidade clássica.

Por outro lado, neste quadro quase patético de carência do conhecimento físico dos mais simples materiais reais, pode parecer surpreendente que, por exemplo, físicos quânticos ${ }^{21}$ tenham podido conceber e levar à prática a construção, funcionamento e aplicação do transístor. Porém, o facto não nos parecerá tão estranho se pensarmos que a máquina a vapor foi inventada antes da termodinâmica e que, na realidade, esta foi construída sobre a engenharia das máquinas térmicas. Resulta daqui que a diferença entre o pensamento científico e o pensamento técnico não pode ser ignorada e que a reivindicação explícita ou implícita, para a ciência clássica, dos grandes sucessos tecnológicos é cegueira auto-infligida ou puro oportunismo. Ou, pondo as coisas de outro modo, a Física contemporânea é apenas um passo (tardio, mas não necessariamente final) do processo do desenvolvimento do conhecimento e domínio do mundo, tributário e indissociável de várias outras formas de pensamento-acção e que com elas partilha, ao nível mais

${ }^{20}$ É esta a razão fundamental (e fundamentalmente única) da fusão, na prática, entre a ciência e a tecnologia ou, mais propriamente, da emergência da ciência contemporânea em radical ruptura com a ciência clássica, de cuja imagem não é, porém, capaz de afastar.

${ }^{21}$ Que, em 1948, Bardeen, Brattain e Schockley tivessem, ou não, licenciaturas em Física e trabalhassem, ou não, como engenheiros nos laboratórios da Bell Telephone, é perfeitamente irrelevante; o facto é que receberam o Nobel da Física em 1956, o que constitui um caso claro de apropriação, por uma ciência que persiste em pensar-se clássica, pura e dedutiva, de um fruto do pensamento tecnológico. 
fundamental, a incerteza, a incompletude, a não-categoricidade e o glorioso direito humano de errar. Se ainda hoje tem algum sentido distinguir ciência de tecnologia, talvez tenha sentido sublinhar, uma vez mais, que a Física, a mais "dura" das nossas ciências actuais, se não limita já a ser Física Teórica e, na sua forma clássica, não passa - no sentido que aqui deixámos apontado - de metáfora hermenêutica de um mundo do qual nunca consegue apreender a complexidade total.

Quando a situação é esta relativamente a fenómenos tão elementares, o que pensar do discurso triunfalista hoje tão frequentemente ouvido a alguns biólogos moleculares sobre os milagres do determinismo genético quando nem sequer é ainda possível definir a identidade físico-química desse conceito-fantasma que é o gene, e a correspondência entre genótipo e fenótipo não passa de uma mera caixa negra de que se conhecem apenas algumas articulações locais virtualmente irrelevantes para a compreensão da ontogénese, ou quando se chama "descodificação" do genoma humano àquilo que não passa de um simples sequenciamento de letras em que não sabemos onde começam e acabam as palavras, ${ }^{22}$ se é que efectivamente as há? ${ }^{23}$ E, então, com que fé podemos aplicar aos nossos corpos e às nossas famílias as inferências extraídas de um tão frágil sistema conceptual? ${ }^{24}$

Seja como for, esperamos ter deixado claro que a ciência, na concepção fundamentalista e oitocentista de AMB e dos sokalistas, não tem, nem pode hoje ter, nada a dizer sobre os reais, concretos e prementes problemas do nosso mundo. Se alguém o tem e o pode é, além da cidadania, a tecnologia, mas, dada a constante interpenetração, até no mesmo indivíduo, da ciência e da tecnologia, a distinção que vale para as disciplinas não vale para as pessoas: os tecnólogos não têm, nesta matéria, qualquer privilégio, nem a interdição pesa necessariamente sobre os cientistas.

\section{Perícia e peritos}

Era o enigma constante da civilização moderna: de que maneira o barato, o de qualidade inferior, o feito à mão, preservava ainda uma semente de verdade $\mathrm{e}$ de vitalidade indestrutível, podia ainda ser uma fonte de salvação.

David Lodge, The Picturegoers

\footnotetext{
${ }^{22}$ Pense-se no verdadeiramente molieriano conceito de "intrão", por exemplo.

${ }^{23}$ No seio das próprias ciências da vida, estes problemas têm sido reconhecidos e têm dado origem a programas de investigação que procuram esclarecer a relação entre os diferentes níveis de organização do "vivo" na ontogénese; é o caso, por exemplo, da Biologia do Desenvolvimento.

${ }^{24}$ Não se trata de um argumento ad hominem de mau gosto, mas não é, certamente, por acaso que é precisamente nos médicos que mais frequentemente se nota a angústia da doença e da morte, a maior hesitação em adoptar as prescrições da sua própria "ciência" e a maior "irracionalidade" no seu cumprimento.
} 
Em face de uma tomada de consciência alarmada e por vezes histérica dos riscos associados a um desenvolvimento descontrolado das actividades próprias da ciência tecnologizada e dos seus aproveitamentos irresponsáveis e oportunistas, o grande fórum organizado pela Academia das Ciências americana, em Março de 1977, sobre os riscos ligados às manipulações genéticas assinala um raro momento simbólico de uma transformação qualitativa das relações do homem com a sua tecnologia. ${ }^{25} \mathrm{Com}$ efeito, essa iniciativa provocou, permitiu e encorajou a expressão pública das diferentes correntes de opinião de todo um país e debates acalorados entre, por um lado, cientistas desejosos de prosseguir aquilo que, além de um modo de vida e um modo de ganhar a vida, consideravam ser a sua missão e, por outro lado, um grande número de cidadãos conscientes ou simplesmente atemorizados com o risco de aplicação irresponsável e/ou em escala insensata de novos conhecimentos científicos e procedimentos técnicos.

Em escala mais local, mas não menos significativa e mesmo mais eficaz, a iniciativa tomada em 1976 pelo município de Cambridge, Massachusetts, representou o advento, na prática, do conceito de controlo pela cidadania do desenvolvimento científico e tecnológico: o problema concreto era o de saber se o município ${ }^{26}$ devia, ou não, proibir a construção pela Universidade de Harvard de um novo laboratório destinado à manipulação genética de bactérias e o que estava em questão era o temor manifestado por alguns cidadãos de que micróbios pudessem vir a escapar-se do laboratório e a desencadear uma epidemia desconhecida e incontrolável. O Conselho Municipal decidiu convocar os principais protagonistas para, em algumas longas sessões públicas, debaterem os seus pontos de vista perante as câmaras das cadeias nacionais de televisão, tendo os cientistas sido avisados de que, se quisessem ganhar a confiança dos deputados municipais, deveriam exprimir-se em linguagem acessível ao comum dos mortais. Na sequência dessas audições públicas, o Conselho decidiu mandatar um grupo de nove cidadãos - só dois dos quais tinham estudos de medicina - para estudar o problema em profundidade. ${ }^{27}$ Ao fim de seis meses de estudos, esses cidadãos con-

\footnotetext{
${ }^{25}$ Não foi certamente por acaso que tal acontecimento se verificou nos Estados Unidos, em que a massa da população é mais vulnerável aos encantos do consumismo tecnológico, e num momento em que a nação americana tremia com o trauma da primeira derrota militar no exterior. Estas circunstâncias podem, porém, provavelmente, ser ignoradas para os efeitos da discussão que propomos.

${ }_{26}$ É notável que a decisão coubesse à autarquia local, e não ao Estado, federado ou federal.

${ }^{27}$ Imagine-se o escândalo e a prova de inteligência que seria se o governo português tivesse tomado decisão semelhante no caso da co-incineração de resíduos industriais perigosos!
} 
cluíram que a iniciativa da Universidade não devia ser proibida, sob a condição de ser consentida uma vigilância adequada sobre o estrito cumprimento das regras de segurança do National Institute of Health. Este procedimento exemplar provou que é possível a não-científicos formar uma opinião independente em matéria de ciência e tecnologia, sobretudo quando lhes for permitido interrogar e escutar especialistas com pontos de vista opostos.

Algo de semelhante, mas com resultados opostos, se passou em $1986 \mathrm{em}$ Salinas, Califórnia, quando a empresa biotecnológica Advanced Genetic Systems (AGS) pretendeu proceder ao primeiro ensaio de campo de uma nova estirpe da bactéria Pseudomonas Syringae que vive sobre as folhas das plantas, onde segrega uma proteína que catalisa a congelação do orvalho em geada branca destrutiva dos tecidos vegetais. A nova estirpe geneticamente manipulada era desprovida dessa proteína glaciogénica e a proposta da AGS era colonizar maciçamente as plantas cultivadas logo na sua eclosão, impedindo, por concorrência, a instalação da variedade glaciogénica. O assunto vinha já de 1983, data em que a AGS obtivera do Recombinant DNA Advisory Committee ${ }^{28}$ autorização para proceder a ensaios de campo; porém, em consequência de um processo judicial interposto pelo conhecido ecologista Jeremy Rifkin, fora obrigada a submeter-se à exigência da Environmental Protection Agency de isolar o terreno da experiência por meio de largas faixas desnudadas, a fim de que as novas bactérias se não pudessem propagar aos terrenos vizinhos não-cultivados e neles proteger as ervas daninhas que, desse modo, poderiam vir a ganhar uma "vantagem competitiva" e assim, em última análise, criar novos problemas à agricultura da região. O município de Salinas nomeou uma comissão de seis cidadãos - todos não-científicos - que procedeu à audição pública dos diferentes intervenientes (responsáveis da empresa, cientistas, ecologistas, habitantes da região). Perante a atitude arrogante e pouco esclarecedora dos representantes da AGS (possivelmente fartos de audições de todos os tipos e confiantes no exemplo positivo de Cambridge), a comissão decidiu que esta deveria ir realizar os seus ensaios alhures, se fosse capaz de mostrar mais respeito pela inteligência dos não-científicos.

Estes são dois bons exemplos de casos em que as comunidades locais e mesmo nacionais se arrogam o direito de uso dos princípios do livre exame e da precaução, e cada vez mais frequentemente vêem reconhecido esse direito.

\footnotetext{
${ }^{28}$ Organismo consultivo em que têm assento não-científicos e mesmo adversários de princípio das manipulações genéticas.
} 
A crescente desconfiança dos cidadãos em relação aos efeitos secundários dos produtos e resíduos das tecnologias modernas não poupa nenhum dos sectores do consumo: tendo sido popularizada na década de $60 \mathrm{com}$ Ralph Nader pelos produtos da indústria automóvel americana, estende-se hoje especialmente à alimentação (bovinos com encefalopatia espongiforme potencialmente propagadora da doença de Kreuzfeld-Jacob, frangos com hormonas, com antibióticos e/ou com dioxinas, peixe com mercúrio, bivalves com toxinas, águas com nitratos, efeitos alergénicos das plantas transgénicas), mas também a outros campos, incluindo mesmo os consumos menos conscientes e economicamente menos valorizados como o do próprio ar (sangues contaminados com SIDA ou hepatite, efeitos teratogénios dos pesticidas clorados, propagação de priões pelas rações animais fabricadas sobre resíduos de carcaças, efeitos carcinogénios da inalação de fibras de amianto, efeitos desozonizantes dos solventes e criogénios polifluorcloretados na alta atmosfera, etc.).

Porém, se a ciência actual sofre das limitações e contradições que descrevemos, que têm os cientistas e os tecnólogos a oferecer sobre estas questões? Obviamente pouco, nada de definitivo e nem sequer sempre muito coerente, tudo sempre condicionado por um de muitos pontos de vista de utilidade, como toda a tecnologia necessariamente o é.

Além disso, as frequentes contradições entre especialistas quando se pronunciam sobre estas matérias são alvo de mediatização intensiva que amplifica as angústias do consumidor entalado entre o que sente e entende como as aterrorizadoras ameaças de uma tecnologia desenfreada e a constantemente denunciada impotência da ciência para a encabrestar. Daqui uma imagem pública muito negativa da ciência e um fascínio temeroso pelos frutos apetecidos de uma tecnologia que aparece como indissociável de um desenvolvimento que ninguém, salvo os ecologistas mais selvagens (benditos sejam os marginais do sistema!), se atreve a pôr em questão.

Peças essenciais nos mecanismos de tomada de decisão, os peritos - geralmente apelidados de cientistas, raramente de tecnólogos - são hoje constantemente expostos como alvos de feira, em parte porque, até uma data muito recente, o seu trabalho se realizava relativamente na sombra, porque o seu lugar nos processos decisórios é ainda muito mal conhecido e mal definido e ainda porque, valendo-se destes dois factos, gerações de políticos cada vez mais cientificamente incultos procuram esconder a génese de decisões motivadas essencialmente por critérios de poder e/ou dinheiro por trás de pretensas perícias "científicas", na realidade institucionalmente montadas de modo a serem acomodatícias aos seus desejos. 
Ora, o grande público e, com ele, boa parte dos cientistas ignora que as recentes crises ${ }^{29}$ alimentares, sanitárias e ambientais obrigaram a repor em questão e a fazer evoluir os funcionamentos das perícias, tanto em Bruxelas como nas capitais dos países mais poderosos da União Europeia, e que profundas reformas tiveram já lugar e outras estão em curso, simultaneamente com um processo burocrático de certificação de qualidade que, se não visando primariamente a qualidade real, pretende, pelo uso de toda uma panóplia de artefactos de prestígio, reconstruir a confiança dos consumidores sem, contudo, estorvar a sagrada liberdade do comércio.

Exemplo típico em que a ciência tecnicizada não foi passiva nem inocente é o das complexas e caras, mas largamente ineficazes, etiquetagens obrigatórias, cuja génese é facilmente retropistável ao AOTC (Acordo sobre os Obstáculos Técnicos ao Comércio), o grande produto da Organização Mundial do Comércio (OMC ou WTO) na sequência da demolição das barreiras alfandegárias e das quotas de importação pelo General Agreement on Trade and Tariffs (GATT). Com efeito, um dos mais modernos conceitos da tecnologia do consumo é o da "traçabilidade", isto é, a possibilidade de retraçar ou retropistar todos os passos do processo produtivo de um bem de consumo. E onde nos leva a traçabilidade? Do ponto de vista da "teoria" económica, esta evolução deveria ir no sentido de uma informação mais abundante, mais pertinente e mais transparente e deveria, portanto, aproximar da prática os pressupostos da teoria: racionalidade e conhecimento perfeito. Porém, como muito bem mostrou o sociólogo D. Torny (1998), o advento das técnicas de traçabilidade em nome da protecção do consumidor consiste apenas em transferir a responsabilidade do produtor para o consumidor que, suposto informado ou informável de todas as especificações do produto, apesar de tudo o escolheu.

Ainda há pouco tempo, existia uma imbricação estreita entre os riscos e a sua gestão política e administrativa, porque as comissões de peritagem eram directamente nomeadas pelos executivos que as geriam e, frequentemente, funcionavam como verdadeiros órgãos dos ministérios e das suas direcções gerais; as nomeações faziam-se na maior parte dos casos por cooptação entre peritos e a publicação das conclusões era frequentemente subtraída ao conhecimento público até deixar de ser relevante. Se, deste modo, a independência das comissões e agências em relação a possíveis

\footnotetext{
${ }^{29}$ O termo "crise" indica a ocorrência de situações de ansiedade social, súbitas, imprevisíveis e potencialmente catastróficas; o seu recente aumento de frequência e amplitude deve também muito aos progressos dos intrumentos de detecção e medida, bem como à constituição progressiva de actores e instituições especificamente dedicados a detectá-las e denunciá-las.
} 
pressões dos grupos económicos ficava até certo ponto assegurada, a independência em relação aos seus superiores hierárquicos não o ficava de todo, até porque, frequentemente, os peritos eram funcionários públicos de carreira. Testemunho deste disfuncionamento do sistema foram os enormes escândalos do sangue contaminado do fim dos anos 80 .

Hoje, no entanto, o neoliberalismo, tomando como bandeira a transparência (glasnost?), propõe soluções mais convenientes, baseadas no público receio do exercício arbitrário da autoridade do Estado, cuja imagem se associa sistematicamente à do cobrador (e mau utilizador) dos impostos. A tendência genérica é para associar estruturas periciais com larga autonomia na definição das suas próprias prioridades e na detecção de problemas sectoriais (saúde, agricultura, alimentação, consumo, ambiente, etc.) a laboratórios de Estado com limitados poderes de gestão, em concorrência com associações profissionais, empresariais e de consumidores que se arrogam o mesmo direito de perícia actuando livremente sobre eles, como efectivos grupos de pressão. Os processos de implementação de perícias tendem cada vez mais a recorrer a concursos públicos abertos não só a organismos públicos, mas também a empresas privadas, frequentemente constituídas a grande velocidade apenas para esse efeito. As perícias são sempre colectivas e organizadas segundo o princípio das task forces ou grupos de missão e, em casos particularmente sensíveis, torna-se necessário desenvolver processos de consulta pública, com garantia de adequada figuração nos relatórios e pareceres finais. Porém, nestes esquemas, as garantias de independência são particularmente problemáticas. Com efeito, mesmo pondo de parte as prestações directas de serviços, o facto de um industrial se dirigir a um investigador é, para este, uma marca de reconhecimento, valiosa sobretudo face à tradicional escassez do reconhecimento público e institucional dos seus méritos científicos, mas é também uma oportunidade, por vezes única, de aprofundar o seu conhecimento do terreno, não devendo, portanto, ser proibida nem coarctada.

À exigência tácita de uma definição do carácter e escopo da perícia, responde-se geralmente com uma fórmula galénica do tipo "conjunto de actividades planeadas para fornecer a um decisor opiniões e recomendações geradas e fundamentadas tão objectivamente quanto possível, elaboradas a partir de inventários e avaliações de conhecimentos acessíveis e reconhecidos, de observações, de inspecções, de auditorias, de experiências, de análises ou investigações diversas, acompanhadas dos necessários juízos profissionais". Nesta óptica, a perícia deveria, portanto, ter por fim fornecer a um decisor opiniões que contenham, devidamente especificadas como tais, ver- 
dades "demonstráveis", probabilidades, e simples plausibilidades, mas também dúvidas, incertezas e informações sobre lacunas de conhecimento e controvérsias associadas. Um perito seria então "uma pessoa cuja competência para a realização de perícias é formalmente reconhecida por um processo de habilitação de um organismo bem definido", preferivelmente universitário, mas mais frequentemente, dada a crónica, mas não inocente, lentidão de resposta das Universidades, uma entidade privada ou semiprivada de natureza pouco mais que burocrática. Um perito é-o, portanto, em relação a outro que tem os seus próprios critérios de escolha em termos de exigências de competência e de graus de independência. Porém, a óbvia circularidade da definição (qui custodiet custodies ipses é também aqui, como sempre, um sério problema) não parece nunca constituir obstáculo à implementação do esquema.

\section{Perícia e controvérsia}

Quanto mais limitada é a formula que se supõe encerrar a verdade, tanto mais completamente se crê possuil-a inteira, e tanto mais nitida e seguramente se supõe distinguir o erro dos outros. Das caracteristicas da Escola adoptada fazem-se regras, medidas, que se aplicam às obras d'arte para as avaliar. A critica é facil, promta e radical: a obra que não é da Escola unica, e a que por isso se não pode aplicar a medida estreita, é necessariamente má: e acabou-se.

J. Batalha Reis, “A Arte, a Crítica e os Artistas Portugueses”, Revista de Portugal, 1892

A divisão da humanidade em duas partes que se excluem mutuamente é essencial às doutrinas totalitárias. Aí não há lugar para posições neutras; qualquer indivíduo tíbio ou frouxo é um adversário, e todo o adversário um inimigo.

Tzvetan Todorov, Memória do mal, tentação do bem

Para muitos de nós, as controvérsias acerca dos riscos tecnológicos, muitas vezes fortemente amplificadas pelos media, contribuem para criar ou manter um ambiente de psicose colectiva em relação aos mais triviais actos da vida quotidiana. Com efeito, a incerteza actual das ciências e da tecnologia sobre estas matérias constitui um dos factores identificados pelos sociólogos como contribuintes para uma percepção aguda da importância dos riscos implicados no simples acto de viver numa sociedade tecnologizada. Para outros, porém, essas controvérsias devem, pelo contrário, ser consideradas como positivas, porque asseguram uma "socialização do risco", supostamente garante da sua tomada em consideração pelos gestores e os políticos. Quer, porém, o seu impacte social seja positivo ou negativo, parece interessante analisar como as controvérsias entre peritos, hoje tão frequentes, 
são vividas e tratadas no seio da comunidade científica e qual a evolução que geram na própria prática pericial. Antes de mais, observa-se toda uma gradação de atitudes, desde a negação pura e simples de qualquer divergência em substância até uma vontade expressa de promover controvérsias e organizar as perícias em torno delas.

A primeira atitude - a que, por facilidade, mas sem conotação pejorativa, chamaremos "negacionista" - consiste em afirmar que os peritos, quando aparentemente em desacordo, estão, na realidade, apenas a examinar aspectos diferentes de uma mesma questão, emitindo, em consequência, opiniões naturalmente discordantes. ${ }^{30}$ Este tipo de atitude permite reafirmar a coerência da comunidade tecno-científica à custa de uma "externalização" da controvérsia, que, assim, parece ficar reduzida a um defeito de percepção do público, do qual os especialistas não teriam culpa. Um tal ponto de vista - que em casos pontuais pode ter plena justificação - tende, quando generalizado, a introduzir a hipótese implícita (decorrente de uma pretensa "objectividade" da ciência) de que os peritos, se reunidos e sujeitos a uma mesma questão rigorosamente definida, chegariam sempre efectivamente a um consenso. Esta hipótese, porém, raras vezes é efectivamente testada, se é que efectivamente pode sê-lo, até porque uma questão rigorosamente definida em matéria de risco ambiental é, frequentemente, uma questão mal posta e, por isso, aberta a contestação antes mesmo de se pensar na respectiva resposta.

A segunda atitude - a que poderemos chamar "denuncionista" - consiste em denunciar, em cada polémica, a incompetência e/ou a parcialidade dos peritos adversários, quer individual, quer globalmente, relativamente à relevância e validade das disciplinas que representam. ${ }^{31} \mathrm{Um}$ dos exemplos mais célebres desta atitude é o Apelo de Heidelberg (http://www.sepp.org/

\footnotetext{
${ }^{30}$ Assim, por exemplo, na controvérsia do Outono de 1999 entre os peritos franceses da AFSSA e a Comissão Científica Europeia sobre o levantamento do embargo às carnes bovinas britânicas, Olivier Godard escreveu na revista Projet: "O episódio reduziu-se a uma incompreensível controvérsia de peritos, quando, na realidade, não existiam divergências científicas significativas quanto aos factos epidemiológicos em si. Eram apenas os pontos de vista que divergiam e as opiniões dos peritos foram publicamente deformadas pelo decisores na gestão política da sua comunicação com a opinião pública." (Godard, 2000: 38).

31 Assim, por exemplo, no caso das plantas transgénicas e do risco de se tornarem infestantes (problema semelhante ao citado caso AGS vs. Salinas), confrontam-se frequentemente a abordagem ecológica, apoiada na teoria das invasões biológicas por espécies estranhas e confirmada na experiência histórica de múltiplas aventuras coloniais, e a abordagem da genética das populações, que recorre aos modelos de difusão de um gene no interior de uma espécie para mostrar como os mecanismo biológicos a controlam. Essas duas abordagens conduzem a apreciações muito diferentes do risco. Daí a tentação de os defensores de cada uma delas denunciarem a outra como irrelevante e não pertinente.
} 
heidelberg_appeal.html), assinado por cerca de 400 intelectuais e cientistas ${ }^{32}$ pouco antes da Conferência do Rio em 1992. Nele pode ler-se:

Nós, abaixo assinados, membros da comunidade científica e intelectual internacional, partilhamos os objectivos da Cimeira da Terra que terá lugar no Rio de Janeiro sob os auspícios das Nações Unidas e aderimos aos princípios da presente declaração. Exprimimos a vontade de contribuir plenamente para a preservação da nossa herança comum, a Terra. No entanto, assistimos preocupados, no alvor do século XXI, à emergência de uma ideologia irracional que se opõe ao progresso científico e industrial e prejudica o desenvolvimento económico e social.

Afirmamos que não existe tal coisa como o "estado de natureza", por vezes idealizada por movimentos que têm tendência a referir-se ao passado - nem provavelmente existiu nunca desde a aparição do homem na biosfera, na medida em que a humanidade desde sempre progrediu pondo a natureza ao seu serviço, e não o inverso.

Aderimos totalmente aos objectivos de uma ecologia científica, baseada na consideração, controlo e preservação dos recursos naturais. No entanto, exigimos formalmente pelo presente apelo que essa consideração, esse controlo e essa preservação sejam fundamentados em critérios científicos e não em preconceitos irracionais. Sublinhamos que numerosas actividades humanas essenciais exigem a manipulação de substâncias perigosas ou se exercem na vizinhança dessas substâncias e que o progresso e o desenvolvimento repousam, desde sempre, sobre um domínio crescente desses elementos hostis, para o bem da humanidade. Consideramos, portanto, que a ecologia científica não é senão o prolongamento desse progresso constante no sentido de melhores condições de vida para as gerações futuras.

A nossa intenção é afirmar a responsabilidade e os deveres da Ciência para com a Sociedade no seu conjunto. No entanto, pomos em guarda as autoridades responsáveis pelo destino do nosso planeta contra toda a decisão que se apoie sobre argumentos pseudocientíficos ou sobre dados falsos ou inadequados. Chamamos a atenção de todos para a necessidade absoluta de ajudar os países pobres a atingir um nível de desenvolvimento sustentável e em harmonia com o do resto do planeta, de os proteger contra os malefícios provenientes das nações civilizadas e de evitar envolvê-los em uma rede de obrigações irrealistas que comprometem a sua independência, tanto como a sua dignidade.

Os piores males que ameaçam o nosso planeta são a ignorância e a opressão e não a ciência, a tecnologia e a indústria cujos instrumentos - desde que geridos de modo adequado - são indispensáveis e permitirão à humanidade vencer, por si mesma e para si mesma, flagelos como a sobrepopulação, a fome e as pandemias.

32 Entre os quais, Alain Bombard (oceanógrafo), Jean Dausset (prémio Nobel da Medicina), Pierre Gilles de Gennes (prémio Nobel de Física), Eugène Ionesco (escritor), Henri Laborit (farmacologista), Hervé le Bras (demógrafo), Jean Marie Lehn (prémio Nobel de Química), André Lichnerowicz (matemático), Haroun Tazieff (vulcanologista). 
No contexto da Conferência do Rio, este texto - que, em primeira análise, parece apenas um benigno enunciado de alguns lugares-comuns inócuos suscitou, naturalmente, reacções violentas por parte de outros cientistas que, considerando-se também legítimos membros da "comunidade" científica, aderiam aos objectivos da Conferência e punham em destaque os contributos da ecologia para uma nova visão do desenvolvimento e do progresso. Não um, mas vários contra-apelos foram assinados nesse espírito depois do Rio.

Mais recentemente, encontra-se essa mesma abordagem em forma radical na noção de junk science (http://skepdic.com/refuge/junkscience.html) desenvolvida pelos defensores da liberdade de acção das biotecnologias para denunciar os seus adversários. Segundo a caricatural definição hoje clássica, "junk-science é a deformação dos factos, o exagero dos riscos e a queda da ciência na política e na ideologia”. Nesta visão, teríamos de um lado os "verdadeiros" cientistas e do outro os meros "activistas" da junk science, cujo objectivo seria o de "restringir a capacidade da ciência para contribuir para a economia e para o avanço do saber”, para já não falar da limitação da liberdade de comércio internacional. Uma das consequências observáveis dessa atitude denuncionista é o imediato desencadear de uma denúncia recíproca, com os cientistas visados a afirmar, por sua vez, que são eles os "verdadeiros" cientistas e que os outros têm uma visão demasiado limitada, redutora e parcial, por se encontrar ligada a interesses económicos e institucionais. O apelo de Heidelberg e seus contra-apelos são exemplo desse tipo de acção e reacção.

Neste debate sobre a junk science, o estatuto da incerteza e do famoso princípio de precaução desempenham papel central. Com efeito, na concepção clássica da perícia, os peritos devem tomar em consideração apenas os factos cientificamente averiguados. Em termos jurídicos, poderia dizer-se que a inovação (produto ou processo) tem que ser considerada inocente (e livre) até que os peritos possam provar a sua perigosidade (não é difícil ver aqui uma sinédoque amplificadora do princípio do direito romano in dubio pro reo, confundindo, não inocentemente, nexo causal com culpa). Inversamente, o princípio de precaução, que incita a tomar em consideração dados ainda incertos e controversos, pode efectivamente conduzir, do ponto de vista do impacte sobre as decisões oficiais, em última instância, a - como denunciam os seus adversários - dar à incerteza um estatuto superior ao dos factos averiguados. Ora, a incerteza é, segundo os seus detractores, o fundamento comum a todos os enunciados da junk science, na medida em que, por definição, em plena emergência da inovação, sobre ela apenas se podem formular hipóteses ainda não verificadas ou enunciar factos mal fundamentados. Este 
ponto de vista extremamente negativo sobre o princípio de precaução está presente no argumento frequentemente invocado de que a aplicação deste princípio desvia a atenção de conhecimentos seguros para riscos hipotéticos e de que a sua aceitação generalizada paralisaria por completo o desenvolvimento das tecnologias e, com elas, o desenvolvimento e o progresso.

De acordo com uma visão, que se pretende um pouco mais equilibrada, do valor da controvérsia, uma solução possível seria "requalificar" os peritos mediante procedimentos de selecção rigorosos que assegurassem a sua independência e o seu reconhecimento pelos seus pares. Assim, o recente relatório de P. Kourilsky e G. Viney ao primeiro ministro francês sob o título Le principe de précaution (Kourilsky e Viney, 2002) preconiza um comprometimento da Academia das Ciências francesa na criação, em todos os domínios da perícia, de uma estrutura única, uma Agência de Perícia Científica e Técnica, encarregada de velar pela qualidade da perícia e de constituir "pólos de informação fiáveis". As repetidas propostas de transferência das perícias para o nível supranacional (v.g., Conselho da Europa), a fim de permitir a congregação dos "melhores especialistas" e de reforçar a sua independência, constituem uma variante desta atitude de que são exemplos o projecto de Autoridade Alimentar Europeia e as regras adoptadas pela Organização Mundial do Comércio para regulação de diferendos. Ora, é importante sublinhar o carácter duvidoso de duas hipóteses subjacentes a esta abordagem: em primeiro lugar a já mencionada, de que ela seria capaz de restabelecer o consenso entre peritos, em segundo lugar, a de que um tal consenso constituiria um progresso qualitativo do conhecimento, por supostamente se aproximar mais da "verdadeira ciência". Por outras palavras, o produto de um debate entre cientistas de competências desiguais seria necessariamente menos "bom" do que o resultante da discussão entre "verdadeiros" peritos devidamente normalizados!

Ao lado desta linha institucionalizante, apareceu recentemente uma outra, de inspiração sociológica: o recurso a uma arbitragem externa, pela via de uma sondagem da opinião pública ou pelo debate entre peritos perante um júri de leigos que proferisse a decisão final. No entanto, o carácter maioritário de uma teoria científica não foi nunca um critério de validação, embora frequentemente seja um critério de financiamento, de honrarias e de nomeações; todas as teorias reconhecidas em dado momento foram, ao surgirem, minoritárias; todas as teorias em dado momento consensuais vieram a ser superadas.

Por mais simpatizante que se seja deste tipo de proposta, fica ainda o problema das modalidades de deliberação, quer entre os peritos, quer entre os leigos, o que conduz a uma outra atitude possível perante as controvér- 
sias: reconhecer-lhes as virtudes e colocá-las no próprio centro do processo pericial, quer este se desenrole na praça pública, quer perante um júri ou ainda in camera. Para isso, basta partir da própria evidência da impossibilidade de garantir a neutralidade e a objectividade perfeitas de um perito individual, impossibilidade que resulta do facto de o papel do perito ser, por definição, o de ir além do âmbito estrito dos seus conhecimentos. Com efeito, partindo desta evidência, não se tratará de denunciar "falsos" peritos, mas, pelo contrário, de reconhecê-los todos (o que não exclui uma selecção prévia das suas competências) como actores válidos de um processo de construção de uma objectividade colectiva baseada na controvérsia.

Tratar-se-ia, portanto, de encenar, em cada caso, uma verdadeira disputatio, no sentido medieval e escolástico do termo, no decorrer da qual todos os pontos de vista seriam expostos e criticados segundo o princípio jurídico do contraditório, não para, finalmente, apurar aquela que é maioritária, mas para identificar e enunciar análises alternativas que, mesmo minoritárias, não pudessem ser excluídas em termos puramente lógicos. Este critério de rigor metodológico é o proposto para a aplicação do princípio de precaução pelos autores do citado relatório Le principe de précaution que, ao mesmo tempo que chamam a atenção para o facto de "um cientista minoritário não ser necessariamente um Galileu”, afirmam:

Deve ser sempre tomada na devida consideração toda a opinião minoritária baseada em uma metodologia maioritariamente reconhecida como válida, considerando que a obrigação dos cientistas não é a de enunciar verdades, o que é impossível, mas a de contribuir para abertura de espaços que contenham verdades.

$\mathrm{Na}$ ausência do necessário caveat, afirmações deste tipo podem ser tomadas como equivalentes a defender, em nome de uma concepção errada de democracia, o erro muito comum segundo o qual uma opinião minoritária tem, pela simples força de ser minoritária, um estatuto próximo do de uma teoria emergente. Ora, o minoritário, que pode não passar de simples erro ou asneira, não é sinónimo de marginal, que implica, esse sim, pensamento criativo divergente.

Desejavelmente, tais "disputas" permitiriam também caracterizar melhor a incerteza que ensombra cada problema e fornecer uma tipologia de incertezas sobre a qual fosse possível basear a construção de medidas de gestão, abandonando os dois enunciados extremos e radicais "na dúvida, pelo réu" (tecnocracia liberal) e "na dúvida, proíba-se" (precaucionismo estrito) e considerando que, na aplicação concreta do princípio de precaução, há lugar para toda uma gama de medidas, desde o reforço dos dispositivos de 
observação e vigilância até à restrição mais ou menos extensa do uso. Isso, porém, pressupõe que os peritos sejam capazes de fornecer uma tipologia das incertezas que permita a aplicação operacionalizada do princípio de precaução, organizada em torno de três eixos de referência: plausibilidade do conhecimento, redutibilidade da incerteza e observabilidade dos fenómenos (Chevassus, 2000).

A plausibilidade de um facto pode definir-se a partir de duas noções, a relevância qualitativa e quantitativa da informação disponível sobre ele e o grau de consenso entre peritos. Estas duas noções, que deveriam, em princípio, poder ser avaliadas de modo semiquantitativo pelos próprios peritos, definem um espaço a duas dimensões que permite ir de (i) uma situação de incerteza radical correspondente à total falta de informação e de consenso (por exemplo, os riscos ligados à transmissão horizontal dos genes das plantas às bactérias) através de (ii) situações de incerteza conflitual correspondente a falta de consenso em presença de informação muito significativa ou (iii) incerteza consensual correspondente a consensos "instintivos" na ausência de informação significativa, até (iv) uma autêntica plausibilidade correspondente a consensos em presença de informação significativa (como parece ser actualmente o caso do risco de transmissão ao homem da BSE) que, no entanto, não pode nunca, em termos científicos, confundir-se com "certeza" ou "verdade". A redutibilidade, por sua vez, designa a plausibilidade do facto de uma investigação intensamente dirigida e executada permitir, em tempo útil, reduzir a incerteza e assim modificar, aumentando ou diminuindo, a plausibilidade de um fenómeno. ${ }^{33}$ Finalmente, a observabilidade refere-se à plausibilidade de um fenómeno hipotético vir a ser detectado por dispositivos de observação existentes ou realizáveis a curto prazo. ${ }^{34}$

Mesmo sem enumerar exaustivamente todas as situações possíveis, seria então fácil verificar, por exemplo, que uma incerteza de média plausibilidade e forte redutibilidade convida a um sério investimento em investigação dirigida, enquanto uma fraca redutibilidade e uma forte observabilidade convidam apenas a uma vigilância reforçada. Concebe-se facilmente que um processo ou um produto, mesmo quando associado a um risco de fraca plausibilidade, mas de observabilidade e redutibilidade fracas, possa conduzir, a título de precaução, a medidas de restrição do uso.

\footnotetext{
33 Por exemplo, a incerteza sobre as distâncias de disseminação do pólen de plantas transgénicas parece facilmente redutível, enquanto a que se refere ao tempo necessário para o aparecimento de resistência dos insectos a herbicidas o é francamente menos.

${ }^{34}$ Por exemplo, a eventualidade de um efeito dos transgénicos sobre a saúde humana aparece como pouco observável, enquanto a transformação de milho transgénico em planta infestante o será facilmente.
} 
Se é verdade que estas definições têm o particular encanto de glorificar com belas palavras conceitos familiares e do senso comum, não é menos verdade que os nossos sábios pais e avós, como a personagem de Molière que fazia prosa sem o saber, já usavam, e bem, esses critérios, deixando a uma certa informalidade consentida o papel de criar espaço para a assunção das lacunas, contradições e círculos viciosos que sob essas belas palavras se escondem.

Porém, uma vez aceites estes princípios de uma paradoxal convergência de um cientismo que se revê na ilusória precisão das definições com um sociologismo rendido à enganadora "clareza dos critérios", estes procedimentos de "disputa" assim controlada e qualificada no interior da "comunidade científica" reconduziriam esta à clássica e utópica "república dos sábios”. Além disso, na opinião dos seus proponentes, procedimentos formalizados deste tipo poderiam - sem que se perceba para quê, se o problema já estava tão bem resolvido entre sábios - prestar-se a alargamento em diálogo com outros representantes da sociedade, naturalmente sob a condição tácita de serem sempre honestamente avaliados e publicamente divulgados os valores dos parâmetros de referência (plausibilidade, relevância, consenso, redutibilidade, observabilidade). O irrealismo destas hipóteses faz lembrar dolorosamente o dos modelos económicos.

Por outro lado, um tal esquema ignora por completo, logo na definição da plausibilidade, o facto elementar de, na génese de todo o risco tecnológico, estar sempre um tácito consenso 'universal' sobre a inocuidade de um novo processo, circularmente baseado no total desconhecimento do risco envolvido. Assim - mesmo sem o luxo desta pretensa formalização -, este tipo de esquema servirá apenas, na melhor das hipóteses, para desencadear um processo de remediação de um risco já estabelecido e conhecido, nunca para aquilo que aos seus proponentes realmente parece importar, a total prevenção do risco.

A nossa posição é um pouco mais desiludida: ao calor e ao brilho da polémica preferimos a tranquilidade da conversação e a produtividade de uma calma divergência, considerando que, tal como a ciência é apenas uma das infindáveis aventuras colectivas de compreensão do mundo, a tecnologia é apenas uma das aventuras individuais da acção arriscada com base nessa compreensão sempre parcial e provisória e a arte - da qual não falámos, mas sobre a qual muito haveria a dizer - um dos modos possíveis de apreender, viver e fruir tudo isto.

Por isso era tão apropriado, na mítica idade de ouro da inconsciência do risco, chamar arte àquilo a que hoje chamamos técnica. 


\section{Referências Bibliográficas}

Chevassus, B. (2000), "Prevention, Precaution, Consumer Involvement: Which Model for Food Safety in the Future?", OCDE Conference on the Scientific and Health Aspects of Genetically Modified Foods, Edimburgo.

Dirac, Paul (1995), The Collected Works, 1924-48. Org. R. H. Dalitz. New York: Cambridge UP.

Godard, Olivier (2000), "Le principe de précaution”, Projet, 261.

Kourilsky, P.; Viney, G. (2002), Le principe de précaution (www.francetelecom.com/fr/ groupe/dossiers/telephonie_sante/actions_prevention/precautions/).

Rocha, Carlos Marinho; Madureira, C. M. Novais (2002), "As diferentes faces da razão. Ou a propósito de uma suposta 'guerra das ciências' e do papão do relativismo", Vértice, 108.

Torny, D. (1998), "La traçabilité comme technique de gouvernement des hommes et des choses, Politix, 44. 